GEOGRAFICKÝ ČASOPIS / GEOGRAPHICAL JOURNAL 73 (2021) 3, 199-218

DOl: https://doi.org/10.31577/geogrcas.2021.73.3.11

\title{
MAPOVANIE A KLASIFIKÁCIA URBÁNNYCH PÔD NA PRÍKLADE MIEST BRATISLAVA, TRNAVA A ŽILINA
}

\author{
Martin Saksa*, Jaroslava Sobocká*, Daniel Szatmári**, Monika Kopecká**, \\ Ján Feranec** \\ * Národné pol’nohospodárske a potravinárske centrum - Výskumný ústav pôdoznalectva a ochrany pôdy, \\ Trenčianska 55, 82109 Bratislava, martin.saksa@nppc.sk jaroslava.sobocka@nppc.sk \\ ** Geografický ústav SAV, Štefánikova 49, 81473 Bratislava, \\ daniel.szatmari@savba.sk, monika.kopecka@savba.sk, feranec@savba.sk
}

\begin{abstract}
Urban soil mapping and classification in the example of cities: Bratislava, Trnava and Žilina

Urban soil survey, mapping and classification is a relatively new but dynamically developing scientific issue worldwide, especially due to increased interest in urban areas in terms of the quality of life of their inhabitants. This survey also seems to not be unified and standardized in recent research. We present the methodical procedure of urban soil mapping, which was primarily based on land cover and land use mapping with using satellite images and subsequently used concept of pedo-urban complex, enabling the mapping of urban soils in large or middle scales. The example of this mapping method was demonstrated in three cities in Slovakia - Bratislava, Trnava and Zilina. We also discuss the issue of classification of urban soils including their diagnostics, which together with their mapping is also inconsistency. Two classification systems, the Slovak Morphogenetic Soil Classification System (MKSP 2014) and the World Reference Base for Soil Resources (WRB 2015) were used for the soil map unit's classification. The created soil maps show a spatial mosaic-like form of pedo-urban complexes and the alternation of several basic soil units, mixed with areas with sealed or other degraded soils. Better knowledge and mapping of urban soils is essential for the development of urban areas and as well as useful tool for urban planning practice.
\end{abstract}

Key words: urban soils, soil mapping, soil classification, pedo-urban complex, Bratislava, Trnava, Žilina

\section{ÚVOD}

Urbánne pôdy sú pôdy vyvinuté v urbanizovanom, priemyselnom, banskom a vojenskom území. Pojem „urbánne pôdy“ ako prvý zaviedol Burghardt (1994) a identifikuje ich ako pôdy vyskytujúce sa $\mathrm{v}$ hraniciach mesta (intraviláne), kde možno nájst': a) prírodné a poloprírodné pôdy (napr. mestské lesoparky), b) pôdy ovplyvnené človekom (pôdy s pôvodnou morfológiou, ale so zmeneným chemizmom, napríklad v dôsledku emisného spádu), c) človekom zmenené pôdy (hlbokou kultiváciou pretvorené pôdne profily) a d) človekom vytvorené umelé pôdy (navážky a vrstvenie pôdneho a iného materiálu). Pojem ,antropogénne pôdy“" používame pre pôdy, ktoré nimi sú v zmysle kritérií daného klasifikačného systému pôd (Bedrna 1995 a Sobocká 1999). Tieto dva termíny sa teda nevylučujú, ale nie sú tiež úplne synonymné.

Výskum urbánnych pôd je relatívne novým vedeckým smerovaním v rámci pôdoznalectva a pedogeografie. Ich výskum začal v 80 . rokoch 20 . storočia, a to hlavne $\mathrm{v}$ Nemecku, kde bol a je enormný tlak na využitie krajiny s potrebou obnovit' staré industriálne miesta, často kontaminované, resp. inak zdevastované. V predchádzajúcom období sa o urbánnych pôdach neuvažovalo ako o pôdach, ale len ako o pozemkoch, ostatných plochách či povrchoch, resp. nevyužitých, alebo naopak 
mnohofunkčných plochách. V posledných dekádach sa však výskum urbánnych pôd rapídne rozvinul (napr. De Kimpe a Morel 2000) a Certini a Scalenghe (2011) hovoria o novej ére - antropocéne, v ktorej antropogénne pôdy a ich výskum budú zohrávat' významnú úlohu. Na Slovensku sa výskumom urbánnych pôd zaoberali napr. Sobocká et al. (2007). Napriek desat'ročiam výskumu urbánnych pôd, ich mapovanie a klasifikácia u nás, ale ani vo svete, nie sú dostatočne metodicky vyriešené a štandardizované. Tento stav možno pripísat' rýchlemu a nekoordinovanému výskumu urbánnych pôd, ktorý je rozptýlený v jednotlivých krajinách a lokálnych výskumných pracoviskách, ako aj rôznym koncepciám a systémom kartografického spracovania a porovnávania týchto pôd na rôznych úrovniach (Levin et al. 2017). Mnoho krajín začalo vyvíjat' vlastné systémy klasifikácie antropogénnych pôd, ktoré sú väčšinou vel'mi rozdielne a s odlišnou koncepciou klasifikácie. Okrem toho existuje terminologická a nomenklatúrna nejednotnost', ako aj definície pôdy v mestách, čo samozrejme st’ažuje štúdium týchto pôd.

V nasledujúcej časti približujeme vývoj klasifikácie antropogénnych pôd v klasifikačných systémoch na Slovensku a uvádzame aj prehl'ad klasifikácie antropogénnych pôd v súčasnosti medzinárodne platnej Svetovej referenčnej báze pre pôdne zdroje (IUSS Working Group 2015).

$\mathrm{V}$ rámci bývalého Československa antropogénny vplyv na pôdu rozoberal už Novák (1955). Za prvú aplikovanú klasifikáciu pôd možno potom považovat' $G e-$ neticko-agronomickú klasifikáciu pôd ČSSR (Němeček et al. 1966 a 1967) použitú pri Komplexnom prieskume pol'nohospodárskych pôd (KPP). Už v tejto je medzi 17 základnými genetickými pôdnymi typmi bývalého Československa zaradená aj antropogénna pôda s hlavnými diagnostickými horizontmi - ornicou (Orh), tiež hlbším humusovým horizontom $(h)$ a premiestneným substrátom $(P)$. V súvislosti $\mathrm{s}$ rozšírením, podmienkami a faktorom pôdotvorného procesu a genézy sa uvádza, že ide o pôdy vytvorené rekultiváciou háld, výsypiek a plôch po t’ažbe niektorých zemín, alebo o pôdy, ktoré výraznou kultiváciou stratili pôvodné vlastnosti pôdneho profilu. V charakteristike sa d'alej uvádza, že ide o pôdy rôznych vlastností podl'a charakteru substrátu a spôsobu rekultivácie (urovnanie povrchu, naváżanie humóznych zemín, zapravenie organických hnojív atd'.). Činnost'ou človeka (rigolovanie a terasovanie) silne pozmenené pôdy sa zarad'ovali ako subtypy príslušných pôdnych typov (subtyp: antropogénna), z ktorých sa vytvárali.

Po roku 1970 boli v Geneticko-agronomickej klasifikácii pôd a v jej doplnkoch, resp. zmenách uplatnených $\mathrm{v}$ legendách pôdnych máp, antropogénne pôdy logicky rozdelené na kultisoly a antropogénne pôdy (Hraško et al. 1991). Pôdne jednotky súpisu Ústavu pre hospodársku úpravu lesov vo Zvolene z roku 1975 v rámci Príručky pre prieskum lesných pôd rozlišujú len rigolovanú pôdu a banskú haldu a súpis VŠLD Zvolen (Śály in Hraško et al. 1991) uvádza antropickú pôdu rigolovú a antropickú pôdu haldovú. Prvý jednotný klasifikačný systém pôd bývalého Československa bol najprv predložený ako návrh VI. Československej pôdoznaleckej konferencie v Nitre v roku 1985 a neskôr bol tiež publikovaný ako Morfogenetický klasifikačný systém pôd ČSFR (Hraško et al. 1991). Bazálna referenčná taxonómia založená na pôdnych kategóriách: skupina - typ - subtyp - varieta - forma, uvádza skupinu pôd antropických s výrazným antropickým (melioračným aj degradačným) pôdotvorným procesom a pốd $\mathrm{s}$ antropicky prerušeným pôdotvorným procesom. V rámci tejto skupiny pôd sú dva základné pôdne typy: kultizem, ako pôda $\mathrm{s}$ antropickým pretvoreným A-horizontom bez d’alších diagnostických horizontov, 
alebo s ich plným pretvorením minimálne do híbky $60 \mathrm{~cm}$ a antrozem, ako pôda $\mathrm{s}$ antropickým umelým A-horizontom na umele vytvorenom podloží.

Od roku 1993 vyšli doposial dve vydania Morfogenetického klasifikačného systému pôd Slovenska, a to v roku 2000 a v roku 2014 (Výskumný ústav pôdoznalectva a ochrany pôdy v Bratislave a Societas pedologica slovaca 2000 a Societas pedologica slovaca 2014). V prvom $\mathrm{z}$ nich, $\mathrm{z}$ roku 2000, došlo len $\mathrm{k}$ úprave a doplneniu jednotlivých pôdnych subtypov, variet a foriem už zavedených pôdnych typov skupiny pôd antropických: kultizem a antrozem, ale vo vydaní z roku 2014 už nastáva zásadné rozšírenie a rozdelenie pôdnej taxonómie na skupinu pôd kultivačných a v rámci nich pôdneho typu kultizem a „nového“ pôdneho typu hortizem a d'alej skupinu pôd technogénnych; v rámci nich pôdneho typu antrozem a pridaného pôdneho typu technozem. Takto celkový počet pôdnych typov na Slovensku vzrástol na 24 , ktoré patria do štrnástich hierarchicky vyšších skupín pôd. $\mathrm{K}$ pôdnym typom kultizem, hortizem, antrozem a technozem boli navyše pridané príslušné pôdne subtypy, variety a formy, ktoré sú ešte rozdelené na eróznoakumulačné pôdne formy, humusové formy, formy antropických zásahov a ostatné formy.

Pri klasifikácii pôd v tomto príspevku sme vychádzali z posledného platného Morfogenetického klasifikačného systému pôd Slovenska MKSP 2014 (Societas pedologica slovaca 2014).

Podl'a neho skupina kultivačných pôd zahŕňa pôdy s výrazným kultivačným pôdotvorným procesom (pôdy in-situ). V prípade kultizemí ide o pôdy s dominantným kultivačným melioračným diagnostickým $(A k j)$ horizontom $>35 \mathrm{~cm}$, s možnými príznakmi alebo aj so zvyškom pôvodného diagnostického horizontu a v prípade hortizemí s dominantným kultivačným hortickým diagnostickým (Ako) horizontom, ktorý zároveň splňa kritériá pre molický $(\mathrm{Am})$ horizont.

Diagnostickým horizontom pre skupinu technogénnych pôd je antropogénny ( $A d)$ povrchový horizont vytvorený človekom z rôznorodých premiestnených materiálov v kumulatívnej híbke $>60 \mathrm{~cm}$. Antropogénne premiestnený materiál (APM) je človekom transportovaný a zmenený materiál, ktorý bol premiestnený l'udskými aktivitami (pomocou mechanizačných prostriedkov alebo manuálne) z iných zdrojových území a tvorí povrchové horizonty. APM nezahrnuje prípady premiestnenia materiálu pri vodnej či veternej erózii, záplavách, prirodzenej koluviácii materiálu alebo prírodných katastrofách, avšak zahíňa prípady deštrukcie pôd vojenských území. APM sú bud' z prírodných materiálov s podielom artefaktov $<10 \%(\mathrm{y})$ a/ alebo prírodno-technogénnych materiálov s podielom artefaktov $10-40 \%(\mathrm{w}) \mathrm{a} /$ alebo technogénnych materiálov s podielom artefaktov $>40 \%$ (x).

Prvá oficiálna verzia Svetovej referenčnej bázy pre pôdne zdroje (WRB) bola prezentovaná na 16. svetovom pôdoznaleckom kongrese v Montpellier v roku 1998 (FAO 1998). Na tomto podujatí bol tiež schválený a prijatý Systém pre koreláciu pôd a medzinárodnú komunikáciu v rámci Medzinárodnej únie pôdoznaleckých vied (IUSS). Po niekol'kých rokoch intenzívneho celosvetového testovania a zbere údajov sa vydáva niekol'ko verzií WRB, a to v rokoch 2006 a 2007 (IUSS Working Group 2006 a 2007) a následne tiež v rokoch 2014 a 2015 (IUSS Working Group 2015), pričom verzia z roku 2015 je posledná a používaná doposial'.

Svetová referenčná báza pre pôdne zdroje (IUSS Working Group 2015) - (d’alej len ako WRB 2015, rozlišuje 32 referenčných pôdnych skupín a dve z nich patria medzi pôdy so silným l'udským ovplyvnením, a to Anthrosols, ako pôdy s dlhodo- 
bým a intenzívnym pol’nohospodárskym využívaním a Technosols, ako pôdy obsahujúce signifikantné množstvo artefaktov (artefacts). Za artefacts sa považujú pevné alebo kvapalné látky, ktoré boli vytvorené alebo podstatne modifikované človekom ako súčast' priemyselného alebo remeselného procesu alebo sa na povrch dostávajú v dôsledku l'udských aktivít $\mathrm{z}$ väčšej híbky. Príkladmi artefaktov sú tehly, keramika, sklo, rozdrvený a triedený kameň, drevené dosky, priemyselný odpad, smeti, spracované ropné produkty, bitúmen, banská hlušina a surová ropa. Diagnostickým kritériom pre Technosols je obsah artefaktov $20 \%$ (objemových, váženým priemerom) alebo viac, do $100 \mathrm{~cm}$ od povrchu alebo po súvislú horninu alebo stmelenú a spevnenú vrstvu, ak je plytšia. Pre Anthrosols je diagnostickým kritériom horizont hortický (hortic), čo je z latinského slova hortus = záhrada, človekom ovplyvnený minerálny povrchový horizont, ktorý je výsledkom hlbokej kultivácie, intenzívnej fertilizácie a/alebo dlhodobej aplikácie l’udských a zvieracích odpadov a iných organických zvyškov (napr. maštal'né hnojivo, kuchynský odpad, kompost a odpady žúmp).

Výskum a mapovanie urbánnych pôd $\mathrm{v}$ mestách $\mathrm{v}$ súčasnosti nadobúda význam najmä v súvislosti s enormne narastajúcou mestskou populáciou (UN 2018). Vel'ké mestá sú čoraz viac vystavené riziku vyplývajúcemu z globálnych dosahov klimatickej zmeny, sucha alebo straty biodiverzity. Zábery a degradácia pôd súvisiace s rastom mestskej populácie toto riziko zvyšujú a spôsobujú prekáźky budúceho rozvoja (Sobocká et al. 2020a).

Posledné štúdie týkajúce sa rôznych techník mapovania a konceptov v rámci výskumu urbánnych pôd vo svete boli uskutočnené v mestách New York (Hernandez a Galbraith 1997, Shaw a Isleib 2017 a Huot et al. 2018), Moskva (Stroganova et al. 1998, Prokofyeva et al. 2011 a 2014 a Prokofyeva a Martynensko 2017), v niekol'kých nemeckých mestách (Holland et al. 1997, Schleuss et al. 1998 a Makowsky a Schneider 2017) a v pol'ských mestách Toruň (Charzyński et al. 2011a, Charzyński a Hulisz 2017 a Huot et al. 2018), Zielona Góra (Greinert 2015 a Huot et al. 2018) a Inowrocław (Pindral et al. 2020).

Hlavným ciel'om príspevku je návrh mapovania, charakteristiky a klasifikácie urbánnych pôd na príklade troch vel'kých miest Slovenska: Bratislavy, Trnavy a Žiliny. Mapovanie urbánnych pôd vychádza z originálneho prístupu spočívajúceho v prvotnom mapovaní krajinnej pokrývky a využitia krajiny v intraviláne miest a $\mathrm{v}$ ich bezprostrednom okolí na základe satelitných snímok a následného využitia konceptu pedo-urbánnych komplexov (Sobocká et al. 2020b) ako priestorových jednotiek, pomocou ktorých možno pôdy v meste mapovat' a hodnotit'.

\section{MATERIÁL A METÓDY}

Mapovanie a klasifikácia urbánnych pôd boli názorne vykonané na troch mestách Slovenska - hlavného mesta SR Bratislavy a dvoch krajských miest - Trnavy a Žiliny. Z hl'adiska geografických pomerov možno konštatovat', že Bratislava je príkladom mesta na vel'kej rieke a rozhraní pohoria a nížiny, Trnava je príkladom mesta na pahorkatine na sprašovej tabuli a Žilina príkladom mesta s reliéfom kotlinovej pahorkatiny.

Prvým krokom bola identifikácia tried krajinnej pokrývky a využitia krajiny aplikáciou počítačom podporovanej vizuálnej interpretácie satelitných snímok SPOT-4/1998, SPOT-5/2007, Sentinel-2/2016, využívajúcej d’alej vektorovú údajovú vrstvu Urban Atlas (2012), rozšírenú legendu Urban Atlas (2012), ako aj úda- 
je o výške budov a parkoviskách zo ZB GIS ${ }^{\circledR}$ (Szatmári et al. 2018 a Feranec et al. 2019a a 2019b).

Celkovo bolo identifikovaných 25 tried krajinnej pokrývky a využitia krajiny, z toho 18 je charakteristických pre urbánny priestor. Minimálna rozloha areálu v zastavanom území je 0,25 ha. Areály sídelnej zástavby boli d’alej delené podl'a podielu nepriepustnej vrstvy (S. L.) na súvislú sídelnú zástavbu (nad $80 \%$ podielu nepriepustnej vrstvy) a nesúvislú sídelnú zástavbu (do $80 \%$ podielu nepriepustnej vrstvy) a tá d’alej na hustú zástavbu, s podielom nepriepustnej vrstvy 51 až $80 \%$, stredne hustú $(31-50 \%)$, riedku $(11-30 \%)$ a vel'mi riedku nesúvislú sídelnú zástavbu (do $10 \%$ podielu nepriepustnej vrstvy). Vo všetkých troch územiach bolo dohromady identifikovaných 2354 areálov tried krajinnej pokrývky a využitia zeme.

Pedo-urbánny komplex (PUK) je geografická a kartografická jednotka na mapovanie systému abiotických, biotických a sociálno-ekonomických komponentov urbánnych ekosystémov v topickej alebo chórickej geografickej dimenzii (Sobocká et al. 2020b).

V d’alšom kroku boli jednotlivým triedam krajinnej pokrývky a využitia zeme expertne priradené charakteristické pôdne jednotky s vyjadrením ich dominancie (pôdne jednotky na prvom mieste), subdominancie (sprievodné pôdne jednotky - :) a lokálneho výskytu (sporadické pôdne jednotky - [ ]), a týmto spôsobom vznikli pedo-urbánne komplexy (tab. 1).

Pôdne jednotky boli klasifikované podl’a dvoch klasifikačných systémov v slovenskom morfogenetickom systéme pôd MKSP 2014 (Societas pedologica slovaca 2014) a v medzinárodnej Svetovej báze pre pôdne zdroje (IUSS Working Group WRB 2015). Posledným krokom bolo vytvorenie pôdnych máp všetkých troch miest, ktoré dostatočne kartograficky reprezentujú pôdne pomery urbánnych priestorov (obr. 1, 2 a 3). S týmto ciel'om boli pôdne pomery prírodných a poloprírodných pôd v okolí urbánnych priestorov klasifikačne zjednodušené. Pôdne mapy sú vzhl'adom na rozsah príspevku vyjadrené len v slovenskom klasifikačnom systéme MKSP 2014 (Societas pedologica slovaca 2014).

\section{VÝSLEDKY}

Z hl'adiska krajinnej pokrývky a využitia krajiny možno pôdy všeobecne rozdelit' na lesné, pol'nohospodárske a urbánne. Z hl'adiska vplyvu človeka potom na prírodné (človekom neporušené pôdy), ktoré sa vyskytujú v širšom území (extraviláne) l'udských sídiel, podobne ako pôdy poloprírodné, s čiastočným vplyvom človeka.

Za poloprírodné pôdy považujeme najmä pol'nohospodárske pôdy využívané ako orná pôda, vinohrady či sady. Tie pôdy, ktoré sa využívajú ako orná pôda (mimo urbánneho priestoru), majú kultizemný pôdny subtyp, čiže majú kultivačný ornicový $(A k p)$ horizont so znakmi kultivácie alebo prímesou agrochemikálií $\mathrm{v}$ hlbke $10-35 \mathrm{~cm}$. Spolu s kultivačným melioračným (Akj) horizontom a kultivačným hortickým (Ako) horizontom patrí do skupiny kultivačných povrchových horizontov $(A k)$. 
Tab. 1. Charakteristické pôdne jednotky tried krajinnej pokrývky a využitia krajiny

\begin{tabular}{|c|c|c|}
\hline $\begin{array}{l}\text { Triedy krajinnej pokrývky a využitia } \\
\text { krajiny }\end{array}$ & $\begin{array}{l}\text { Pôdne jednotky } \\
\text { podl'a MKSP } 2014 \\
\text { (Societas pedologica } \\
\text { slovaca 2014) }\end{array}$ & $\begin{array}{l}\text { Pôdne jednotky } \\
\text { podl'a IUSS Working } \\
\text { Group WRB (2015) }\end{array}$ \\
\hline $\begin{array}{l}\text { Súvislá sídelná zástavba } \\
(\text { S.L. }>80 \%)\end{array}$ & ANä/ae $[\mathrm{ANä/au}]$ & TC-ek-rc [TC-ub] \\
\hline $\begin{array}{l}\text { Nesúvislá hustá sídelná zástavba } \\
\text { (S.L. } 51-80 \%)\end{array}$ & $\begin{array}{l}\text { ANä/ae: ANä/au : } \\
\text { ANô/au }\end{array}$ & $\begin{array}{l}\text { TC-ek-rc : TC-ub: } \\
\text { RG-tn }\end{array}$ \\
\hline $\begin{array}{l}\text { Nesúvislá stredne hustá sídelná zástavba } \\
\text { (S.L. } 31-50 \%)\end{array}$ & $\begin{array}{l}\text { ANä/au: ANô/au: } \\
\text { ANä/ae }\end{array}$ & $\begin{array}{l}\text { TC-ek-rc : RG-tn: } \\
\text { TC-ub }\end{array}$ \\
\hline $\begin{array}{l}\text { Nesúvislá riedka sídelná zástavba } \\
\text { (S.L. } 11-30 \%)\end{array}$ & KTm/az: ANä/ae & AT-ht : TC-ek-rc \\
\hline $\begin{array}{l}\text { Nesúvislá vel'mi riedka sídelná zástavba } \\
\text { (S.L. } \leq 10 \%)\end{array}$ & $\mathrm{KTm} / \mathrm{az}[\mathrm{ANä/ae}]$ & AT-ht [TC-ek-rc] \\
\hline Izolovaná sídelná zástavba & KTm/az, ANä/ae & AT-ht, TC-ek-rc \\
\hline $\begin{array}{l}\text { Školy, zdravotnícke zariadenia, obchody } \\
\text { a úrady }\end{array}$ & $\begin{array}{l}\text { ANä/ae: ANä/au : } \\
\text { ANô/au }\end{array}$ & $\begin{array}{l}\text { TC-ek-rc: TC-ub: } \\
\text { RG-tn }\end{array}$ \\
\hline Výrobné a skladovacie areály & ANä/ae: ANô/au & TC-ek-rc: RG-tn \\
\hline Autostrády a pril'ahlé areály & TZä/ae [ANô/w/au] & TC-lc [RG-im.tn] \\
\hline Ostatné cesty a pril'ahlé areály & TZä/ae [ANô/w/au] & TC-lc [RG-im.tn] \\
\hline Železnice a pril’ahlé areály & TZä/ae [ANô/w/au] & TC-lc [RG-im.tn] \\
\hline Areály prístavov & ANä/ae [ANä/au] & TC-ek-rc [TC-ub] \\
\hline Areály letísk & ANä/au: ANä/ae & TC-ub : TC-ek-rc \\
\hline $\begin{array}{l}\text { Areály t’ažby nerastných surovín } \\
\text { a skládky odpadu }\end{array}$ & $\begin{array}{l}\text { TZä/ad } \\
\text { TZô/ap (x) }\end{array}$ & $\begin{array}{l}\text { TC-sp } \\
\text { TC-ga (tx) }\end{array}$ \\
\hline Areály výstavby (nové zóny) & $\mathrm{ANä/ae}[\mathrm{ANô} / \mathrm{ak}]$ & TC-ek-rc [RG-te] \\
\hline Areály krajiny bez súčasného využitia & ANä/au: ANä/ae & TC-ub: TC-ek-rc \\
\hline $\begin{array}{l}\text { Areály sídelnej vegetácie: } \\
\text { Cintoríny: }\end{array}$ & $\begin{array}{l}\text { ANô/au } \\
\text { ANä/ae: ANä/au : } \\
\text { ANô/au }\end{array}$ & $\begin{array}{l}\text { RG-tn } \\
\text { TC-ek : TC-ub: } \\
\text { RG-rc }\end{array}$ \\
\hline Areály športu a zariadení vol'ného času & ANô/au: ANä/ae & RG-tn: TC-ek-rc \\
\hline Orná pôda s jednoročnými plodinami & \multicolumn{2}{|c|}{$\begin{array}{l}\text { Poloprírodné pôdy (pôdny subtyp: kultizemná, } \\
\text { doplnkový kvalifikátor Aric) }\end{array}$} \\
\hline Trvalé kultúry (vinohrady) & \multicolumn{2}{|c|}{$\begin{array}{l}\text { Poloprírodné pôdy (pôdna forma: rigolovaná, } \\
\text { doplnkový kvalifikátor: Escalic) }\end{array}$} \\
\hline Trávne porasty - lúky a pasienky & \multicolumn{2}{|l|}{ Poloprírodné pôdy } \\
\hline Heterogénne pol'nohospodárske areály & $\mathrm{KTm} / \mathrm{az}[\mathrm{ANä/ae}]$ & AT-ht [TC-ek-rc] \\
\hline Sady & \multicolumn{2}{|l|}{ Poloprírodné pôdy } \\
\hline Lesy & \multicolumn{2}{|l|}{ Prírodné pôdy } \\
\hline Prirodzené lúky & \multicolumn{2}{|l|}{ Prírodné pôdy } \\
\hline Močiare & \multicolumn{2}{|l|}{ Prírodné pôdy } \\
\hline \multicolumn{3}{|l|}{ Povrchové vody } \\
\hline $\begin{array}{l}\text { ANä/ae - antrozem iniciálna/ekranická } \\
\text { ANä/au - antrozem iniciálna/urbická } \\
\text { ANô/au - antrozem rekultivačná/urbická } \\
\text { KZm/az - kultizem modálna/záhradná } \\
\text { TZä/ae - technozem iniciálna/ekranická } \\
\text { ANô/e/au - antrozem rekultivačná/kontaminovaná imisná/u } \\
\text { TZä//ad - technozem iniciálnal/haldová } \\
\text { TZô//ap }(\mathrm{x}) \text { - technozem rekultivačná/depóniová (kontamin } \\
\text { ANô/ak - antrozem rekultivačná/nástielková }\end{array}$ & \multicolumn{2}{|c|}{$\begin{array}{l}\text { TC-ek-rc - Ekranic Technosol (Relocatic) } \\
\text { TC-ub - Urbic Technosol } \\
\text { RG-tn - Regosol (Tranportic) } \\
\text { AT-ht - Hortic Technosol } \\
\text { TC-lc - Linic Technosol } \\
\text { RG-im.tn - Regosol (Immissic, Transportic) } \\
\text { TC-sp - Spolic Technosol } \\
\text { TC-ga (tx) - Garbic Technosol (Toxic) } \\
\text { RG-te - Regosol (Technic) }\end{array}$} \\
\hline
\end{tabular}




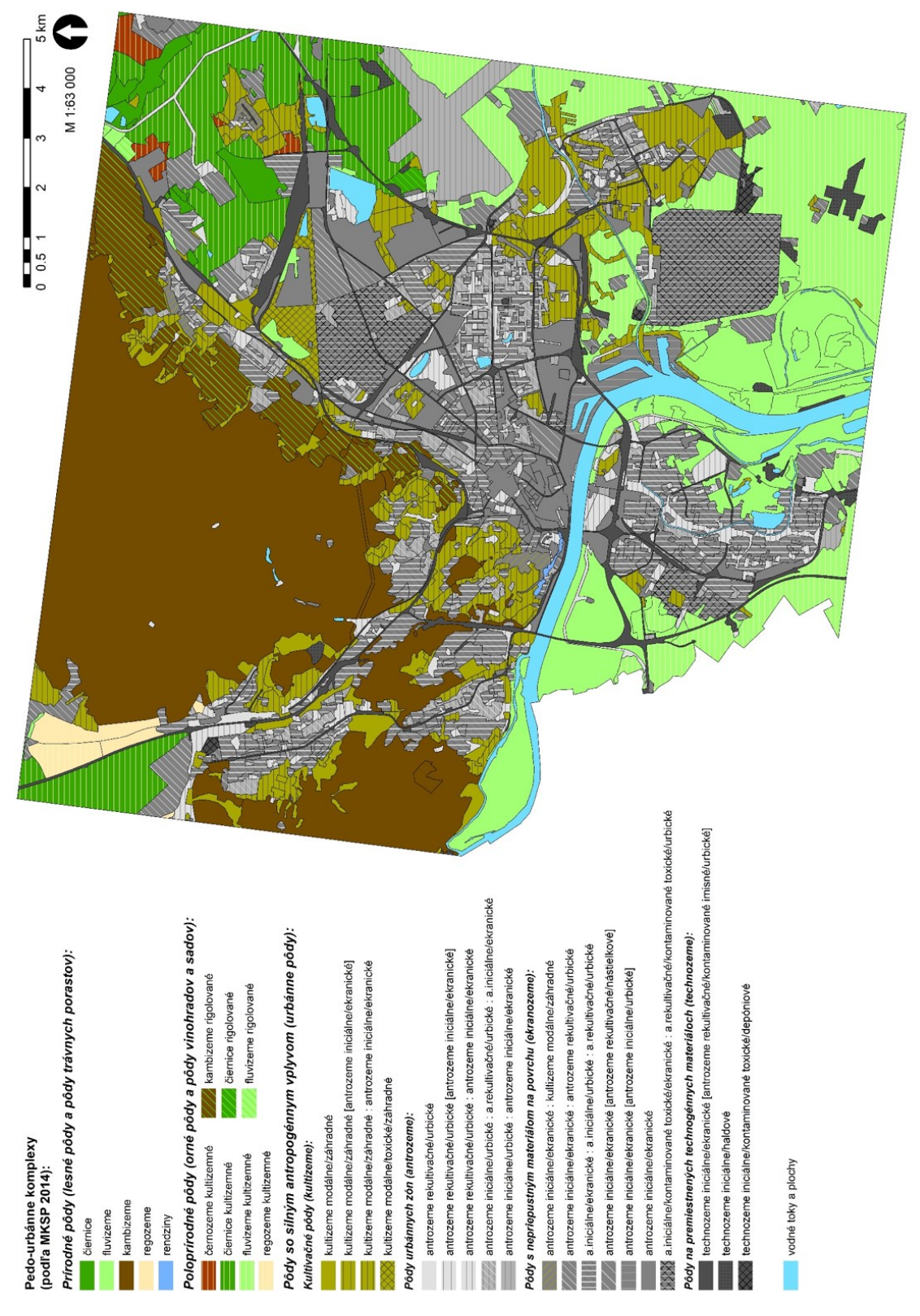

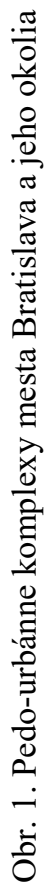




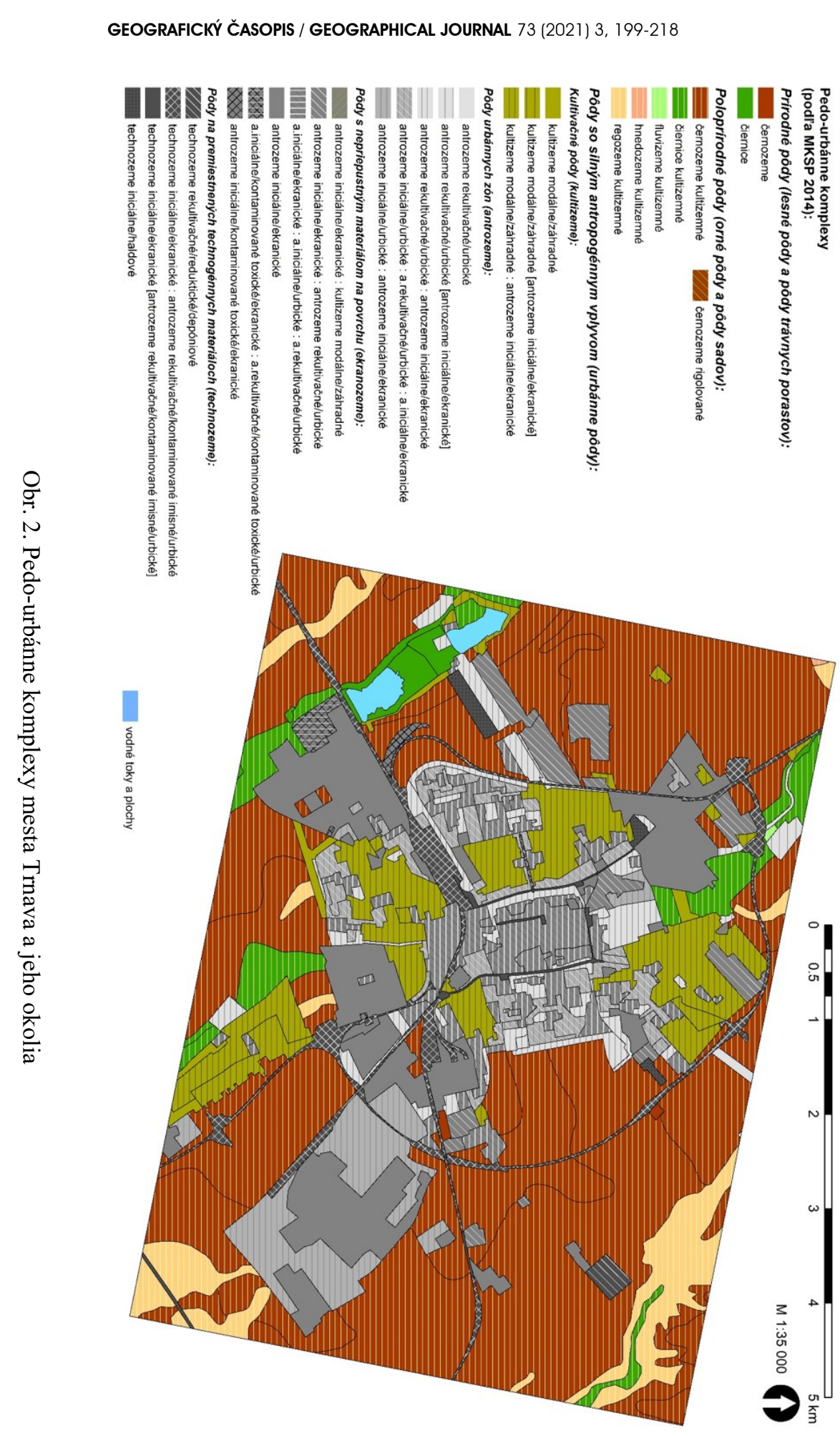


GEOGRAFICKÝ ČASOPIS / GEOGRAPHICAL JOURNAL 73 (2021) 3, 199-218

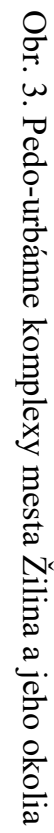
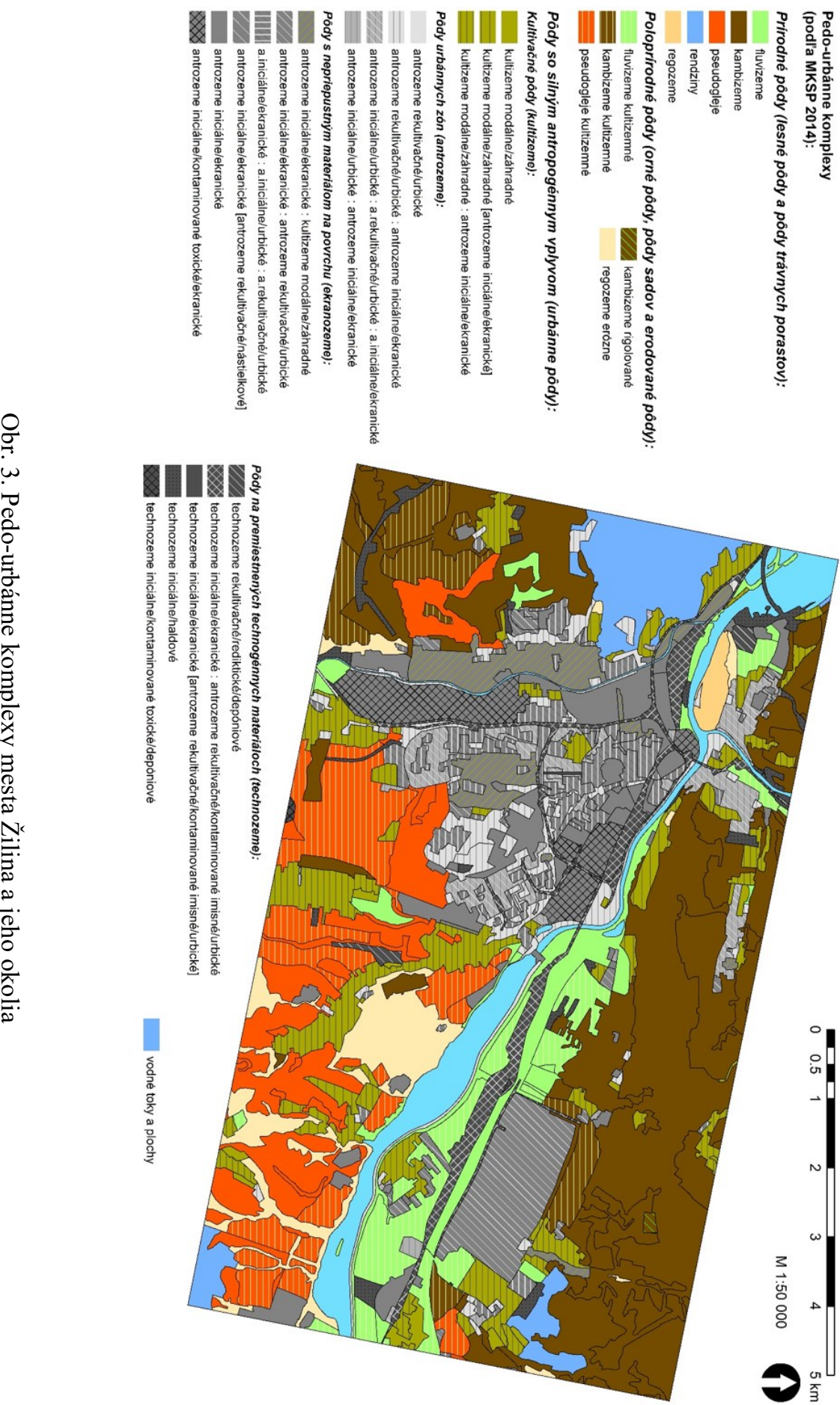
V medzinárodnej klasifikácii pôd (IUSS Working Group WRB 2015) sa orba vyjadruje doplnkovým kvalifikátorom Aric, čo znamená oraný do híbky viac ako $20 \mathrm{~cm}$ od povrchu pôdy. Pôdnu formu rigolovanú uplatňujeme pri kultivácii pôd rigolovaním vo vinohradoch, sadoch a chmel'niciach. V medzinárodnej klasifikácii pôd (IUSS Working Group WRB 2015) možno terasované pôdy vinohradov označit' doplnkovým kvalifikátorom Escalic, čo znamená vyskytujúci sa na terasách vytvorených človekom.

Pôdy so silným antropogénnym vplyvom, alebo tiež urbánne pôdy, možno všeobecne rozdelit' do štyroch skupín na pôdy kultivačné - kultizeme, nezastavané pôdy urbánnych zón - antrozeme, pôdy s nepriepustným materiálom na povrchu „ekranozeme“" (všeobecne používaný termín pre pôdy s nepriepustným povrchom, môžu byt' antrozeme aj technozeme) a pôdy vyvinuté na premiestnených technogénnych materiáloch - technozeme. V nasledujúcej časti textu uvádzame charakteristiku ôsmich hlavných pôdnych jednotiek vyskytujúcich sa vo všetkých troch mapovaných mestách.

\section{Kultizeme}

\section{Kultizeme modálne/záhradné}

Všeobecne ide o všetky pôdy v rámci intravilánu obcí, ktoré sú človekom kultivované s ciel'om dosiahnutia lepšej pôdnej úrodnosti a pol'nohospodárskej produkcie. Kultivačný melioračný ( $A k j$ ) horizont (diagnostický pre kultizeme) je humusový povrchový horizont pretvorený obrábaním, hnojením alebo inými kultivačnými zásahmi, ktorý má nasledujúce vlastnosti: hrúbku viac ako $35 \mathrm{~cm}$, značný obsah organického uhlíka $(\mathrm{C} \geq 0,3 \% \mathrm{hm}$.), prímes podpovrchových a/alebo artefaktov a znaky kultivácie - znaky orby, homogenizácia vrstvy, zretelný až ostrý prechod, farebne odlíšený, zhutnenie na jeho spodnej hranici alebo prímes agrochemikálií, vápenca, maštal'ného hnoja, pozberových zvyškov a iných organicko-minerálnych zúrodňovacích komponentov MKSP 2014 (Societas pedologica slovaca 2014).

Ide najmä o intenzívne kultivované pôdy v záhradkárskych oblastiach a pridomových záhradách pridávaním zúrodňovacích komponentov, ako sú komposty, pesticídy a iné (pôdna forma: záhradná). Nachádzajú sa v nesúvislej sídelne zástavbe (so stupňom nepriepustného povrchu do $80 \%$ ), kde vo vel'mi riedkej až riedkej nesúvislej sídelnej zástavbe sú dominantnými pôdnymi typmi a v stredne hustej až hustej sídelnej zástavbe staršieho, vidieckeho typu (s pridomovými záhradami) sú sprievodnými pôdnymi typmi k dominantným antrozemiam.

Majú zväčša priaznivejšie produkčné vlastnosti ako orná pôda $v$ okolí (v extraviláne). Vplyv človeka na pôdu je spravidla pozitívny a takéto pôdy sa vyznačujú svojou vyššou kvalitou a v urbánnom prostredí plnia viaceré funkcie s pozitívnym účinkom na životné prostredie človeka.

V klasifikačnom systéme existuje niekol'ko subtypov kultizemí, s príznakmi alebo aj so zvyškom pôvodného diagnostického horizontu: regozemná, fluvizemná, černozemná, čiernicová, hnedozemná, luvizemná, kambizemná, pseudoglejová, glejová, slanisková a slancová. Bez podrobnejšieho terénneho prieskumu je však ich určenie vel'mi problematické a $\mathrm{z}$ tohto dôvodu sme ostali len pri subtype modálna (bez d’alších diagnostických horizontov) alebo ich príznakov. Vzhl’adom na fyzicko-geografické pomery mapovaných miest možno v Bratislave hypoteticky očakávat' výskyt kultizemi fluvizemných a kultizemí kambizemných, ako aj vel'mi kvalitných kultizemí černozemných a kultizemí čiernicových, ktoré dominujú 
v Trnave. V Žiline sú to potom najmä kultizeme kambizemné a kultizeme pseudoglejové. Problematické je tiež určenie pôdneho typu hortizem v urbánnom prostredí. Bez terénneho prieskumu možno ich výskyt len predpokladat', a to najmä v Trnave a v černozemno-čiernicovej oblasti na juhu, juhovýchode a východe Bratislavy. Tieto pôdy majú kultivačný hortický (Ako) diagnostický horizont $\mathrm{s}$ hrúbkou $\geq 35$ $\mathrm{cm}$, ktorý splńa farebné kritérium pre horizont molický, vysoký obsah organického uhlíka (C $\geq 1 \% \mathrm{hm}$.), biologické oživenie (koprolity, zooedafón a iné) viac ako $20 \%$ objemových, obsah $\mathrm{P}_{2} \mathrm{O}_{5}$ v $1 \%$ kyseline citrónovej $>250 \mathrm{mg} \cdot \mathrm{kg}^{-1}$ a spravidla slabo alkalickú reakciu.

V medzinárodnej klasifikácii WRB 2015 (IUSS Working Group WRB 2015) označujeme takéto pôdy ako Hortic Anthrosols, čiže pôdy s dlhodobým a intenzívnym pol'nohospodárskym využívaním a diagnostickým hortickým (hortic) horizontom, ktoré sa nachádzajú všade na svete, kde l’udia zúrodňujú pôdu domácim odpadom a hnojivom. Charakteristické sú najmä pre Európu a Cínu ako pôdy záhradné.

\section{Antrozeme a technozeme}

Skupina pôd technogénnych zahŕňa pôdy s pôdotvornými procesmi výrazne ovplyvnenými technogénnou činnost'ou človeka (pôdy ex-situ), s diagnostickým antropogogénnym horizontom (Ad), iniciálnym (Adi) alebo rekultivačným (Adr), vytvoreným z prevažne premiestnených prírodných a prírodno-technogénnych materiálov v prípade antrozemí a $\mathrm{z}$ prevažne premiestnených technogénnych materiálov v prípade technozemí. Za substráty (materiál) prírodného pôvodu sa považujú: piesky, hliny, íly, štrky, zahlinené štrkopiesky, kamenitý až balvanovitý materiál, zmiešaný hlinito-štrkovo-piesčitý a kamenitý materiál, rašelinový a humolitový materiál. Za substráty prírodno-technogénneho pôvodu sa považujú: hlušinový odpad banského priemyslu, hlušinový odpad metalurgického priemyslu a zmiešané technologicko-rekultivačné materiály. Nakoniec za substráty technogénneho pôvodu pri technozemiach sa považujú: stavebný odpadový materiál (s komponentmi tehla, betón, izolačný materiál, malta, cement, kovy, sklo, smola atd'.), popolčeky (produkt spracovania čierneho a hnedého uhlia, horlavý odpad), troska a škvara (odpad spracovania železa a farebných kovov), smetiskový odpad (s komponentmi domového a komunálneho odpadu), odkaliská (kalový odpad), industriálny odpad (odpadové produkty chemického, metalurgického, plastikového, drevospracujúceho, farbiarskeho a plynárenského priemyslu) a tiež biotechnologický odpad (kompostovaný organický odpad).

Podl’a medzinárodnej klasifikácie pôd (IUSS Working Group WRB 2015) takéto pôdy zarad'ujeme do referenčnej pôdnej skupiny Technosols. Ich diagnostickým kritériom je $20 \%$ alebo viac artefaktov, čo nemusia splńat' všetky urbánne pôdy. V takých prípadoch sa zarad'ujú medzi Regosols.

Najčastejšími pôdnymi jednotkami antrozemi a technmozemí v urbánnom prostredí sú:

\section{Antrozeme rekultivačné/urbické}

Pôdy urbánnych zón s povrchovým antropogénnym rekultivačným (Adr) horizontom obohateným o humus a vytvoreným rekultiváciou $\mathrm{z}$ antropogénne premiestnených materiálov prírodného pôvodu (antropogénny rekultivačný prírodný Adry horizont) a prírodno-technogénneho pôvodu (antropogénny rekultivačný prírodnotechnogénny Adrw horizont), s hrúbkou viac ako $10 \mathrm{~cm}$. Vznikli navezením organo -minerálneho materiálu na umelo vyrovnané alebo spustnuté plochy v urbanizova- 
ných oblastiach a pozdĺž dopravných komunikácií (pôdna forma: urbická), pričom $\mathrm{v}$ druhom prípade možno pridat' aj pôdnu varietu: kontaminovaná imisná, čiže je imisne antropogénne kontaminovaná (v zmysle platných noriem) aspoň čast' pôdneho profilu.

Ked’že tieto pôdy zväšša neobsahujú viac ako $20 \%$ artefaktov nemožno ich podl'a medzinárodnej klasifikácie pôd (IUSS Working Group WRB 2015) zaradit' medzi Technosols, ale len medzi Regosols, presnejšie Regosols (Transportic), kde kvalifikátor Transportic vyjadruje, že majú na povrchu vrstvu $30 \mathrm{~cm}$ alebo hrubšiu $\mathrm{z}$ pevného alebo tekutého materiálu, ktorá bola cielenou l'udskou aktivitou navezená zo zdroja územia mimo bezprostrednej blízkosti pôdy, obyčajne pomocou mechanizmov a bez zásadného pretvorenia alebo rozmiestnenia prírodnými silami.

Antrozeme rekultivačnélurbické dominujú v areáloch športu a zariadení vol'ného času, ale najmä $\mathrm{v}$ areáloch sídelnej vegetácie - mestské parky, trávniky a aleje. Ako sprievodné pôdne jednotky sa vyskytujú tiež v nesúvislej hustej a stredne sídelnej výstavbe, v areáloch škôl, zdravotníckych zariadení, obchodov a úradov a tiež v priemyselných a obchodných areáloch. S pôdnou formou kontaminovaná imisná tvoria tiež pril'ahlé areály cestných komunikácií a železníc. V rámci IUSS Working Group WRB (2015) potom ide o Regosols (Immissic, Transportic).

$\mathrm{V}$ moderných novovybudovaných mestských štvrtiach sa vyskytujú antrozeme rekultivačné/nástielkové, kde pôdna forma nástielková je s krátkodobou organickou, minerálnou alebo priemyselnou pokrývkou povrchu pôdy hrubou $<10 \mathrm{~cm}$ (napr. drevotriesky, mulčovacie textílie, fólie a iné). V medzinárodnej klasifikácii (IUSS Working Group WRB 2015) označujeme takéto pôdy ako Regosols (Technic), pričom doplnkový kvalifikátor Technic vyjadruje, že pôdy majú $10 \%$ alebo viac (objemových, váženým priemerom) artefaktov vo vrchných $100 \mathrm{~cm}$ od povrchu pôdy alebo do súvislej horniny, alebo stmelenej či stvrdnutej vrstvy, ak je plytšia.

\section{Antrozeme iniciálne/urbické}

Pôdy urbánnych zón, ktoré nemajú rekultivačný, ale len antropogénny iniciálny (Adi) horizont $\mathrm{v}$ primitívnom štádiu vývoja, vytvorený $\mathrm{z}$ antropogénne premiestnených materiálov prírodného pôvodu (antropogénny iniciálny prírodný Adiy horizont) a prírodno-technogénneho pôvodu (antropogénny iniciálny prírodno-technogénny Adiw horizont) s hrúbkou $1-10 \mathrm{~cm}$.

V medzinárodnej klasifikácii (IUSS Working Group WRB 2015) označujeme takéto pôdy ako Urbic Technosols, kde principiálny kvalifikátor Urbic znamená: majúci vrstvu $20 \mathrm{~cm}$ alebo hrubšiu do $100 \mathrm{~cm}$ od povrchu pôdy s $20 \%$ alebo viac (objemových, váženého priemeru) artefaktov obsahujúcich $\geq 35 \%$ (objemových) stavebnej sute a odpadu z l'udských sídiel.

Vyskytujú sa najmä v staršej obytnej zástavbe. Ďalej sa vyskytujú ako sporadické až sprievodné pôdne jednotky v súvislej a hustej sídelnej zástavbe a tiež v riedkej a vel'mi riedkej sídelnej zástavbe a ako dominantné pôdne jednotky v nesúvislej stredne hustej sídelnej zástavbe. Takisto sa vyskytujú v priemyselných a obchodných areáloch, areáloch prístavov a letísk a opustených sídelných areáloch.

\section{Antrozeme iniciálnelekranické}

Patria medzi pôdy s nepriepustným materiálom na povrchu, ktoré možno všeobecne označit' ako „ekranozeme“. Majú antropogénny iniciálny horizont a neprie- 
pustný alebo polopriepustný technogénny materiál na povrchu pôdy, ako je betón, asfalt, dlažba s hrúbkou menšou ako $20 \mathrm{~cm}$, ktorý pokrýva viac ako $80 \%$ polypedónu.

V medzinárodnej klasifikácii (IUSS Working Group WRB 2015) ide o Ekranic Technosols (Relocatic), kde principiálny kvalifikátor Ekranic znamená, majúci technický materiál (technic hard material) do $5 \mathrm{~cm}$ od povrchu pôdy, pričom za technický materiál sa považuje spevnený materiál, ktorý je výsledkom priemyselného procesu $\mathrm{s}$ vlastnost'ami podstatne odlišnými od prírodných materiálov a je súvislý alebo má vol’ný priestor do $5 \% \mathrm{v}$ horizontálnom smere. Príkladmi technického materiálu sú asfalt, betón alebo súvislá vrstva opracovaných kameňov. Doplnkový kvalifikátor Relocatic vyjadruje premodelovanie l'udskou činnost'ou in situ do híbky $100 \mathrm{~cm}$ (napr. hlbokou orbou, opätovným zakopávaním pôdnych jám alebo niveláciou pôdy) a po celej zmene so žiadnym vývojom horizontu najmenej medzi $20 \mathrm{~cm}$ a $100 \mathrm{~cm}$ od povrchu pôdy.

Takéto pôdy sú charakteristické pre zastavané územia a intravilány obcí. Dominujú v súvislej sídelnej zástavbe, nesúvislej hustej sídelnej zástavbe, v areáloch škôl, zdravotníckych zariadení, obchodov a úradov a tiež v priemyselných a výrobných areáloch.

Prevládajú tiež v areáloch cintorínov, ktoré majú špeciálne postavenie medzi areálmi sídelnej zelene. Pôdy cintorínov možno všeobecne nazvat' ako „nekrozeme“/,nekrosoly“. Ide o komplex pôdnych jednotiek (IUSS Working Group WRB 2015): Ekranic Technosols, Urbic Technosols a Relocatic Regosols, ktoré takto popísali Charzyński et al. (2011b) a podla MKSP 2014 (Societas pedologica slovaca 2014) ide o komplex pôdnych jednotiek: antrozem iniciálnal ekranická, antrozem iniciálna/urbická a antrozem rekultivačná/urbická.

\section{Technozeme rekultivačné/reduktické/depóniové}

Technozeme sú pôdy vytvorené z prevažne premiestnených technogénnych materiálov v kumulatívnej hrúbke $>60 \mathrm{~cm}$. V prípade pôdneho subtypu rekultivačná ide o prítomnost' antropogénneho rekultivačného technogénneho (Adrx) horizontu, ktorý vznikol zo substrátu technogénneho pôvodu. Sú to pôdy, ktoré vznikli navezením organicko-minerálneho materiálu na skládky odpadov prevažne chemicky aktívneho materiálu - depóniá komunálnych a priemyselných odpadov s možnost'ou metagenézy (pôdna varieta: reduktická, pôdna forma: depóniová).

V medzinárodnej klasifikácii pôd (IUSS Working Group WRB 2015) takéto pôdy označujeme ako Garbic Technosols, kde principiálny kvalifikátor Garbic znamená majúci vrstvu $20 \mathrm{~cm}$ alebo hrubšiu, do $100 \mathrm{~cm}$ od povrchu pôdy, s $20 \%$ alebo viac (objemových, váženým priemerom) artefaktov, obsahujúcich $35 \%$ alebo viac (objemových) organického odpadu.

Tieto pôdy vznikli na rekultivovaných skládkach odpadu. Majú len lokálne priestorové rozšírenie. V mapovaných územiach sú to rekultivované skládky odpadu v Trnave a v Považskom Chlmci v rámci Žiliny.

\section{Technozeme iniciálne/ekranické}

Podobne ako Antrozeme iniciálne/ekranické patria medzi pôdy s nepriepustným materiálom na povrchu - „ekranozeme“, ale majú antropogénny iniciálny technogénny (Adix) horizont. 
V medzinárodnej klasifikácii pôd (IUSS Working Group WRB 2015) označujeme takéto pôdy ako Linic Technosols, pričom principiálny kvalifikátor Linic vyjadruje majúci súvislú, vel'mi slabo priepustnú až nepriepustnú stavebnú geomembránu akejkolvvek hrúbky do $100 \mathrm{~cm}$ od povrchu pôdy.

Vyskytujú sa ako pôdy pod cestnými komunikáciami a železnicami, preto majú líniový charakter priestorového rozšírenia.

\section{Technozeme iniciálne/haldové}

Tieto pôdy sa vyvinuli z premiestnených, spravidla prírodno-technogénnych a technogénnych substrátov, akými sú t’ažobné a priemyselné haldy, výsypky, výplne, odkaliská a podobne.

V medzinárodnej klasifikácii pôd (IUSS Working Group WRB 2015) označujeme takéto pôdy ako Spolic Technosols, kde principiálny kvalifikátor Spolic znamená: majúci vrstvu $20 \mathrm{~cm}$ alebo hrubšiu, do $100 \mathrm{~cm}$ od povrchu pôdy, s $20 \%$ alebo viac (objemových, váženým priemerom) artefaktov, obsahujúcich $35 \%$ alebo viac (objemových) priemyselného odpadu (banská hlušina, vyt'ažený materiál, troska, popol, sut', atd'.).

V mapovaných územiach reprezentujú najmä iniciálne nekontaminované pôdy na starých t’ažobných haldách a výsypkách, najmä po t’ažbe štrkopieskov (v Bratislave). Majú len lokálne rozšírenie.

\section{Technozeme iniciálne/kontaminované toxické/depóniové}

Pri týchto pôdach je toxicky antropogénne alebo geogénne kontaminovaná (v zmysle platných noriem) aspon̆ čast' pôdneho profilu.

V medzinárodnej klasifikácii pôd (IUSS Working Group WRB 2015) ich označujeme ako Spolic Technosols (Toxic), kde doplnkový kvalifikátor Toxic znamená: majúci v niektorej vrstve do $50 \mathrm{~cm}$ od povrchu pôdy toxické koncentrácie organických alebo anorganických látok, iných ako sú ióny $\mathrm{Al}, \mathrm{Fe}, \mathrm{Na}, \mathrm{Ca}$ a $\mathrm{Mg}$ alebo sú rádioaktívne nebezpečné pre človeka.

Z hl'adiska l'udského zdravia sú to nebezpečné pôdy, často označované ako environmentálne zát'aže, aj ked' ich priestorové rozšírenie nebýva vždy rozsiahle.

V Bratislave ide najmä o nasledovné environmentálne zátaže: skládka Agátová ulica v Dúbravke, areál Istrochem v Novom Meste, areál bývalého závodu Matador v Petržalke, lokalita južne od PD Podunajské Biskupice, d’alej skládka Čierny les, areál bývalého závodu Gumon, vtokový objekt Malého Dunaja a širší priestor závodu Slovnaft $v$ Ružinove a najmä mediálne známa skládka na Vrakunskej ceste vo Vrakuni. V Trnave je to čast' bývalého areálu Trnavských automobilových závodov (v likvidácii), rušňové depo Cargo, a. s., a dve čerpacie stanice pohonných hmôt na Bratislavskej a Nitrianskej ulici. V Žiline sú environmentálnymi zát’ažami bývalý areál ZVL, neriadená skládka odpadov Považský Chlmec, rušňové depo Cargo, a. s., východné priemyselné pásmo (areál SAD a Považské chemické závody - Celulózka) a čerpacia stanica pohonných hmôt Montáža. V širšom okolí Žiliny sem patrí aj skládka popolčeka (odkalisko) v Rosine, odkalisko popolčeka v Trnovom a neriadené skládky tuhého komunálneho odpadu v Gbel'anoch a Tepličke nad Váhom. 


\section{DISKUSIA}

Pôdne mapy miest Bratislava, Trnava a Žilina sú výsledkom konceptuálneho pôdneho mapovania na základe princípu pedo-urbánneho komplexu, bez uskutočnenia terénneho výskumu. Možno ich považovat' len za akýsi model pôdnych pomerov v intravilánoch mapovaných miest a v ich bezprostrednom okolí. Pre detailnejšie poznanie pôdnych pomerov urbánnych priestorov by bolo potrebné vykonat' cielený pedologický výskum. Ten sa čiastočne uskutočnil v Bratislave (Sobocká et al. 2007). Z jeho poznatkov sme čerpali aj v tomto príspevku.

Pri použití dvoch klasifikačných systémov MKSP 2014 (Societas pedologica slovaca 2014) a (IUSS Working Group WRB 2015) v urbánnom prostredí sa objavilo aj niekol'ko klasifikačných problémov. Pri použití klasifikácie IUSS Working Group WRB (2015) je sporným miestom zaradenie evidentne urbánnych pôd do poslednej referenčnej pôdnej skupiny v systéme - Regosols, kam spadajú ostatné pôdy. IUSS Working Group WRB (2015) v tomto naráža na fakt, že jej základným princípom nie je genéza pôd, ale ide o klasifikáciu založenú na deskripcii pôd, jej diagnostických horizontov, diagnostických vlastností a diagnostických materiálov. Takto sa mnoho urbánnych pôd, ktoré nespíñajú základné klasifikačné kritérium pre Technosols (kam by mali logicky - geneticky patrit') vzhl'adom na obsah viac ako $20 \%$ artefaktov, následne klasifikuje „len“ ako Regosols. Nevhodné sa nám tiež javí pomenovanie referenčnej pôdnej skupiny Anthrosols ako pôd s dlhým a intenzívnym pol'nohospodárskym využitím. Vhodnejší by bol termín Cultisols, ked’že ide o l'udskú kultiváciu a skôr pozitívny vplyv na pôdu.

Morfogenetická klasifikácia MKSP 2014 (Societas pedologica slovaca 2014) naopak - ovel'a lepšie reflektuje antropogénny vplyv na pôdu, kde kultizeme a hortizeme predstavujú pôdy pretvorené kultiváciou, antrozeme pôdy s povrchovým horizontom vytvoreným človekom z prírodných a prírodno-technogénnych materiálov a technozeme ako pôdy s povrchovým horizontom vytvoreným človekom z technogénnych materiálov - umelo vytvorené pôdy.

Modelové mapovanie urbánnych pôd samozrejme tiež odkrýva celý rad d'alších klasifikačných problémov. Uvedomujeme si, že nie všetky pôdy v záhradkárskych osadách a pridomových záhradách majú kultivačný melioračný horizont $\mathrm{s}$ hrúbkou viac ako $35 \mathrm{~cm}$ a teda môžu byt' klasifikované ako kultizeme. Takisto je otázny výskyt a priestorové rozšírenie hortizemi $\mathrm{v}$ týchto areáloch, čiže pôd s ešte kvalitnejším kultivačným hortickým, človekom vytvoreným povrchovým horizontom. Domnievame sa, že takéto pôdy sa vyskytujú v urbánnom prostredí len fragmentálne. Aj z tohto dôvodu by sme navrhovali zvážit' zaradenie hortizeme do zoznamu pôdnych typov Slovenska a uprednostnit' skôr subtyp hortizemná pre pôdny typ kultizem, namiesto jej subtypov černozemná a čiernicová.

Pri mapovaní kultizemí v sídelnej zástavbe je dôležité rozlišovat' sídelnú zástavbu (a to akejkol'vek hustoty) s vidieckym charakterom, s pridomovými záhradami staršieho typu, pretože $\mathrm{v}$ modernej sídelnej zástavbe, aj charakteru rodinných domov, zväčša človekom kultivované pôdy chýbajú a sú nahrádzané najmä rekultivačnými a nástielkovými subtypmi, resp. pôdnymi formami antrozemi až technozemí.

Rozlišovanie pôdnych subtypov iniciálna a rekultivačná je pri mapovaní urbánnych pôd tiež sporné. Výstavba väčšiny sídlisk na Slovensku prebehla v socialistickom období s vel'koplošnými a etapovitými stavebnými postupmi, pri ktorých bola pôvodná pôda na vel'kej rozlohe odstránená alebo rozrušená a upravovaná až po 
ukončení stavebných prác. Rozprestretie a zarovnanie (nivelácia) pôdneho materiálu však nemožno považovat' za rekultivačný proces. Pôdny subtyp iniciálna sme preto prirad'ovali skôr $\mathrm{k}$ starším sídliskám a subtyp rekultivačná $\mathrm{k}$ tým modernejším, kde mohli byt' použité aj moderné rekultivačné postupy pozostávajúce aj z niekol'koročných technických a biologických procesov.

Problematické sa tiež javí mapovanie urbánnych pôd z hl'adiska zrnitosti (textúry pôdy), ktoré by bolo v kontexte aplikovaných výskumov mestského prostredia ešte ovel'a vhodnejším aplikačným nástrojom než mapovanie pôdnych pomerov prostredníctvom pôdnej taxonómie. Treba si však uvedomit', že práve pri finálnych stavebných prácach na sídliskách nemusela byt' vždy, a väčšinou ani nebola, použitá zemina z miesta výstavby, čo značne komplikuje konceptuálne mapovanie pôd $\mathrm{z}$ hl'adiska ich zrnitosti.

\section{ZÁVER}

Vytvorené pôdne mapy ukazujú, že urbanizovaná krajina sa vyznačuje priestorovou mozaikovitou formou pedo-urbánnych komplexov a striedaním niekol'kých základných pôdnych jednotiek, ktoré sú spoločné pre každý urbánny priestor, bez ohl'adu na jeho fyzicko-geografické danosti. $Z$ tohto dôvodu je potrebné $\mathrm{k}$ ich mapovaniu pristupovat' odlišným spôsobom ako pri pôdnom mapovaní v pol'nohospodárskej či lesnej krajine.

Mapovanie urbánnych pôd $\mathrm{v}$ tomto príspevku je založené na prvotnom mapovaní krajinnej pokrývky a využitia krajiny v mestskom prostredí, resp. jeho intraviláne. Krajinná pokrývka a využitie krajiny je v podstate dominantným faktorom geografickej regionalizácie pôdnych pomerov urbánneho prostredia, na rozdiel od okolitej pol’nohospodárskej, prípadne lesnej krajiny, kde ním je spravidla georeliéf. V kombinácii s následným konceptom pedo-urbánneho komplexu, ako základnej mapovacej jednotky so striedaním nepriepustného povrchu a rôznych typov urbánnych, človekom silne ovplyvnených pôd (rôzne pôdne jednotky urbánnych pôd), sa nám tento metodický postup javí ako vel'mi vhodný nielen na zlepšenie poznatkov o urbanizovanej krajine všeobecne, ale aj na hodnotenie kvality urbánnych pôd a ich ekosystémových služieb.

Pôdu považujeme za klúčový komponent urbánneho ekosystému s rôznymi environmentálnymi funkciami. Urbánna pôda slúži ako: 1) základňa pre život a životné prostredie človeka, 2) základňa pre život a životný priestor zvierat, rastlín a pôdnych organizmov, 3) komponent prírodnej a hydrologickej rovnováhy, 4) filtračné a pufračné médium (acidita a t'ažké kovy), 5) transformačné médium (úloha mikroorganizmov), 6) komponent živinového cyklu, 7) archív prírody a kultúry, 8) médium pre infiltráciu, zadržiavanie a prúdenie vody a 9) regulačné teleso klímy s chladiacim efektom. Lepšie poznanie a mapovanie urbánnych pôd je preto nevyhnutným nástrojom pre rozvoj mestských území a zabezpečenie lepšej kvality života a zdravia jej obyvatel'ov.

Moderné stavebné postupy v posledných dvoch desat'ročiach sa však zameriavajú na zintenzívnenie zástavby na úkor vol’ných plôch s pôdou, ktorú navyše nahrádzajú umelo vytvorenými pôdami a rôznymi nástielkovými povrchmi, ktoré nie sú schopné plnit' ekosystémové a environmentálne funkcie. Nazdávame sa, že mapovanie urbánnych pôd by malo preto mat' svoj priemet najmä do územnoplánovacej praxe, kde doposial' dochádza napríklad k zámene bonitovaných pol'nohospodárskych pôd s pôdami urbánnymi so silným antropogénnym vplyvom. 
Momentálne neexistujú žiadne medzinárodne akceptované smernice pre urbánne pôdy a ich mapovanie, preto je každý príspevok $\mathrm{k}$ tejto téme vel'mi cenným. V súvislosti so stále narastajúcim tlakom na riešenie problémov mestského prostredia je rozvoj pedogeografického prístupu mimoriadne naliehavým. Pre urbanistov a projektantov urbanizovanej krajiny je zároveň dôležitou výzvou akceptovat' popis, klasifikáciu a mapovanie urbánnych pôd ako užitočný nástroj v rámci územnoplánovacej praxe.

Príspevok bol vypracovaný v rámci riešenia projektu APVV-15-0136 Vplyv nepriepustného pokrytia pôdy na klímu miest v kontexte klimatickej zmeny.

\section{LITERATÚRA}

BEDRNA, Z. (1995). Príspevok ku klasifikácií a mapovaniu pôd pozmenených antropogénnou činnostou. Geografický časopis, 47, 119-129.

BURGHARDT, W. (1994). Soils in urban and industrial environments. Zeitschrift für Pflanzenernährung und Bodenkunde, 157, 205-214. DOI: https://doi.org/10.1002/ jpln.19941570308.

CERTINI, G., SCALENGHE, R. (2011). Anthropogenic soils are the golden spikes for the Anthropocene. The Holocene, 21, 1269-1274. DOI: https://doi.org/10.1177/ 0959683611408454.

De KIMPE, C. R., MOREL, J. L. (2000). Urban soil management: A growing concern. Soil Science, 165, 31-40. DOI: 10.1097/00010694-200001000-00005.

FAO (1998). World reference base for soil resources. ISSS-ISRIC-FAO. World Soil Resources Report No. 84, Rome (FAO).

FERANEC, J., HOLEC, J., ŠŤASTNÝ, P., SZATMÁRI, D., KOPECKÁ, M. (2019a). Visualising a comparison of simulated urban heat islands: A case study of two Slovakian cities. In Fujita, H., ed. Advances in Cartography and GIScience of the ICA. Vol. 1. Tokyo (International Cartographic Association), pp. 1-8. Dostupné na: https:// doi.org/10.5194/ica-adv-1-6-2019 [cit.: 21-07-2021].

FERANEC, J., KOPECKÁ, M., SZATMÁRI, D., HOLEC, J., ŠŤASTNÝ, P., PAZÚR, R. BOBÁLOVÁ, H. (2019b). A review of studies involving the effect of land cover and land use on urban heat island phenomenon, assessed by means of the MUKLIMO model. Geografie, 124(1), 383-101.

GREINERT, A. (2015). The heterogeneity of urban soils in the light of their properties. Journal of Soils and Sediments, 15, 1725-1737. DOI: https://doi.org/10.1007/s11368014-1054-6.

HERNANDEZ, L. A., GALBRAITH, J. M. (1997). Soil survey of LaTourette Park, Staten Island. Lincoln (USDA - Natural Resources Conservation Service and Cornell University).

HOLLAND, K., LEHMANN, A., STAHR, K. (1997). Bodeninventur in Stuttgart. In Blume, H. P., Schleuss, U., eds. Bewertung anthropogener Stadtböden. Abschlussbericht des BMBF-Verbundvorhabens der Universitäten Berlin (TU), Halle-Wittenberg, Hohenheim, Kiel und Rostock sowie des „Büro für Bodenbewertung“, Kiel. Kiel (Schriftenreihe Institut für Pflanzenernährung und Bodenkunde \& Ökologie Zentrum, Universität Kiel) 38, 281-307.

HRAŠKO, J., LINKEŠ, V., NĚMEČEK, J., NOVÁK, P., ŠÁLY, R., ŠURINA, B. (1991). Morfogenetický klasifikačný systém pôd ČSFR (Bazálna referenčná taxonómia, Referenčný klasifikačný systém, Klasifikácia pôdotvorných substrátov). Bratislava (VÜPÚ).

HUOT, H. HULISZ, P., CHARZYNSKI, P., GREINERT, A. (2018). Urban soil resources of medium-sized cities in Poland: A comparative case study of Torun and Zielona Góra. Journal of Soils and Sediments, 18, 358-372. DOI: https://doi.org/10.1007/s11368-0161596-x. 
CHARZYŃSKI, P., BEDNAREK, R., CHMURZYŃSKI, M. (2011a). Właściwości gleb tworzących się na budowlach miasta Torunia. In Jankowski, M., eds. Wybrane problemy genezy, systematyki, uźytkowania i ochrony gleb regionu kujawsko-pomorskiego. Wrocław, Warszawa (PTSH, PTG), pp. 97-116.

CHARZYŃSKI, P., BEDNAREK, R., ŚWITONIAK, M., ŻOŁNOWSKA, B. (2011b) Ekranic technosols and urbic technosols of Torun Necropolis. Geologija, 53, 179-185.

CHARZYNSKI, P., HULISZ, P. (2017). The case of Torun, Poland. In Levin, M. J., ed. Soils within cities. Stuttgart (Catena-Schweizerbart), pp. 123-128.

IUSS Working Group WRB (2006). World reference base for soil resources 2006. World Soil Resources Report No. 103, Rome (FAO).

IUSS Working Group WRB (2007). World reference base for soil resources 2006. First Update 2007. World Soil Report No. 103. Rome (FAO).

IUSS Working Group WRB (2015). World reference base for soil resources 2014, update 2015 International soil classification system for naming soils and creating legends for soil maps. World Soil Resources Report No. 106. Rome (FAO).

LEVIN, M. J., KIM, K.-H. J., MOREL, J. L., BURGHARDT, W., CHARZYŃSKI, P., SHAW, R. K. (2017). Soil within cities (Global approaches to their sustainable management - composition, properties, and functions of soil of the urban environment). Stuttgart (Catena-Schweizerbart).

MAKOWSKY, L., SCHNEIDER, J. (2017). The case of Germany. In Levin, M. J., ed. Soils within cities. Stuttgart (Catena-Schweizerbart), pp. 113-122.

NĚMEČEK, J., DAMAŠKA, J., HRAŠKO, J., BEDRNA, Z., KALENDA, M., ZUSKA, V., TOMÁŠEK, M. (1966). Prieskum pol'nohospodárskych pôd ČSSR. Súborná metodika, čast' A, Metodika terénneho prieskumu, zostavovania pôdnych máp, kartogramov a sprievodných zpráv. Geneticko-agronomická klasifikácia pôd ČSSR. Bratislava (Laboratórium pôdoznalectva).

NĚMEČEK, J., DAMAŠKA, J., HRAŠKO, J., BEDRNA, Z., ZUSKA, V., TOMÁŠEK, M., KALENDA, M. (1967). Průzkum zemédèlských půd ČSSR. Souborná metodika, Díl první, Metodika terénního průzkumu, sestavovaní půdních map, kartogramů a průvodních zpráv. Geneticko-agronomická klasifikace půd ČSSR. Praha (Ministerstvo zemědělství a výživy).

NOVÁK, V. (1955). O potřebě typologické revise kulturních půd. Acta Universitatis Agriculturae et Silviculturae. Zborník Vysoké školy zemědělské a lesnické fakulty v Brně, 2, $125-134$.

PINDRAL, S., KOT, R., HULISZ, P., CHARZYŃSKI, P. (2020). Landscape metrics as a tool for analysis of urban pedodiversity. Land Degradation \& Development, 31, 22812294. DOI: https://doi.org/10.1002/ldr.3601.

PROKOFYEVA, T. V., MARTYNENKO, I. A., IVANNIKOV, F. A. (2011). Classification of Moscow soils and parent materials and its possible inclusion in the classification system of Russian soils. Eurasian Soil Science, 44, 561. DOI: https://doi.org/10.1134/ S1064229311050127.

PROKOFYEVA, T. V., GERASIMOVA, M. I., BEZUGLOVA, O. S., BAKHMATOVA, K. A., GOLEVA, A. A., GORBOV, S. N., ZHARIKOVA, E. A., MATINYAN, N. N., NAKVASINA, E. N., SIVTSEVA, N. E. (2014). Inclusion of soils and Soil-like bodies of urban territories into the Russian soil classification system. Eurasian Soil Science, 47, 959-967. DOI: https://doi.org/10.1134/S1064229314100093.

PROKOFYEVA, T. V., MARTYNENKO, I. A. (2017). The case of Moscow, Russia. In Levin, M. J., ed. Soils within cities. Stuttgart (Catena-Schweizerbart), pp. 129-137.

SCHLEUSS, U., WU, Q., BLUME, H. P. (1998). Variability of soils in urban and periurban areas in Northern Germany. Catena, 33, 255-270. DOI: https://doi.org/10.1016/ S0341-8162(98)00070-8.

SHAW, R. K., ISLEIB, J. T. (2017). The case of the New York City Soil Survey Program, United States. In Levin, M. J., ed. Soils within cities. Stuttgart (Catena-Schweizerbart), pp. 107-112. 
SOBOCKÁ, J. (1999). Súčasný stav poznania a hodnotenia antropogénnych pôd na Slovensku. Rostlinná výroba, 45, 237-244.

SOBOCKÁ, J., JADUUĎ, M., RUŽEKOVÁ-POLTÁRSKA, K., ŠURINA, B. (2007). Urbánne pôdy (priklad Bratislavy). Bratislava (Výskumný ústav pôdoznalectva a ochrany pôdy).

SOBOCKÁ, J, SAKSA, M., FERANEC, J., SZATMÁRI, D., HOLEC, J., BOBÁLOOVÁ, H., RÁSSOVÁ, A. (2020a). Mapping of environmentally sensitive areas in Bratislava city. Journal of Soil and Sediments. DOI: https://doi/org/10.1007/s11368-020-02682-4.

SOBOCKÁ, J., SAKSA, M., FERANEC, J., SZATMÁRI, D., KOPECKÁ, M. (2020b). A complexity related to mapping and classification of urban soils (A case study of Bratislava city, Slovakia). Soil Science Annual, 71, 321-333. https://doi.org/10.37501/ soilsa/127525.

SOCIETAS PEDOLOGICA SLOVACA (2014). Morfogenetický klasifikačný systém pôd Slovenska. Bazálna referenčná taxonómia. Druhé upravené vydanie. Bratislava (NPPC - VÚPOP).

STROGANOVA, M. N., MIAGKOVA, A. D., PROKOFYEVA, T. V., SKVORTSOVA, I. N. (1998). Soils of Moscow and urban environment. Moscow (PAIMS).

SZATMÁRI, D., KOPECKÁ, M., FERANEC, J., SVIČEK, M. (2018). Rozširená legenda Urban Atlas 2012. Bratislava (Geografický ústav SAV).

UN (2018). World urbanization prospects: The 2018 revision. Dostupné na: https:// population.un.org/wup/Download/ [cit.: 10-05-2021]

URBAN ATLAS (2012). https://land.copernicus.eu/local/urban-atlas

VÝSKUMNÝ ÚSTAV PÔDOZNALETVA A OCHRANY PÔDY V BRATISVAVE, SOCIETAS PEDOLOGICA SLOVACA (2000). Morfogenetický klasifikačný systém pôd Slovenska (Bazálna referenčná taxonómia). Bratislava (Výskumný ústav pôdoznalectva a ochrany pôdy).

ZBGIS http://www.gku.sk/gku/produkty-sluzby/zbgis/

\author{
Martin Saksa, Jaroslava Sobocká, Daniel $S$ z a t mári, \\ Monika Ko p e cká, Ján F e ra n e c

\section{URBAN SOIL MAPPING AND CLASSIFICATION IN THE EXAMPLE OF CITIES: BRATISLAVA, TRNAVA AND ŽILINA}

Urban soils are soils developed in urban, industrial, mining and military areas. Urban soil research is a relatively new scientific direction in the field of soil science and pedogeography. This trend began in the 1980s in connection with the enormous pressure on land use with the need to restore old industrial sites, often contaminated or otherwise devastated. In the previous period, urban soils were not considered as soils, but only as a land, other areas, or surfaces, respectively, unused or, conversely, multifunctional areas. In recent decades, research on urban soils has developed rapidly.

Despite decades of research of urban soils, their mapping and classification in our country and the world, has not been sufficiently methodically solved and standardized. In this paper, we present the development in the classification of urban or anthropogenic soils in the classification systems in Slovakia and we also present an overview of the two applied classifications, currently valid, National Morphogenetic Soil Classification and the World Base for Soil Resources.

The main goal of this paper is to map, describe and classify urban soils in the example of three larger cities: the capital city Bratislava and regional centres Trnava and Žilina. The elaborated soil maps show that a spatial mosaic-like form of pedo-urban complexes and the alternation of several basic soil units, which are common to each urban area, regardless of 
their physical-geographical conditions. For this reason, it is necessary to approach their mapping in a different way than when soil mapping in an agricultural or forest landscape.

The mapping of urban soils was primarily based on land cover and land use mapping using satellite images of urban areas and in their immediate surroundings. Land cover and land use is basically a leading factor in the geographical regionalization of the soil conditions in the urban environment, in contrast to the surrounding agricultural or forest landscape, where there is usually a leading factor of regionalization georelief. In combination with the subsequently used concept of pedo-urban complex, which is a basic mapping unit with alternation of impermeable surface and various types of urban, anthropogenic heavily influenced soils (various urban soil units), this methodological procedure seems not to be very suitable for not only improving knowledge of the general urban environment, but also the need to evaluate urban soils and their ecosystem services.

Research and mapping of urban soils in the cities is currently gaining importance, especially in connection with the enormously growing urban population. Big cities are increasingly exposed to the risks of global impacts of climate change, drought or loss of biodiversity. Land consumption, soil sealing and soil degradation related to urban population growth increase this risk and cause obstacles to future development.

There are currently no internationally accepted guidelines for urban areas and their mapping, so any contribution to this topic is valuable and in the context of ever-increasing pressure to address urban issues. The development of this scientific direction is essential and an urgent challenge for urban planners to include a description, classification and mapping of urban soils as a useful tool for urban planning practice.

Article first received: February 2021

Article accepted: June 2021 